\title{
Pemahaman dan Kontribusi Gereja Terhadap Hak Penyandang Disabilitas
}

(Survey kepada Gereja-gereja Baptis di Semarang Barat)

\author{
Karnawati \\ Sekolah Tinggi Teologi Baptis Indonesia \\ $\underline{\text { Karnawati@stbi.ac.id }}$
}

\begin{abstract}
Jesus taught and preached the gospel of the Kingdom of God and eliminated all diseases and weaknesses among the nations. Evidence of Jesus fulfilling spiritual and physical needs to those in need. The task of the church is not just teaching the word of God, but also giving attention to the church and people who have not believed. One concern that needs to be given is the fulfillment of accessible rights for persons with disabilities. The purpose of this study is to explore the understanding and contribution of Baptist Churches in the West Semarang region regarding the fulfillment of the rights of persons with disabilities. This type of research is qualitative using interview instruments, and observation. The results obtained by church leaders see people with disabilities as individuals who have deficiencies and incompleteness in the body, as people with permanent disabilities and have special needs and need attention compared to normal people in general. So that the involvement of persons with disabilities to serve God in the fellowship of believers is not obligatory. And the contribution given by the church is only up to the charity stage, which is to provide assistance in the form of basic food, visiting services, shuttle services, and death insurance programs. Physical accessibility in the form of a ramp with a slope that is too sharp, a staircase for stairs that are too high, and toilet seats that can help physical disability is more comfortable.
\end{abstract}

Keywords: environment, teaching and learning process, Jesus

Yesus mengajar dan memberitakan Injil Kerajaan Allah serta melenyapkan segala penyakit dan kelemahan di antara bangsa. Bukti Yesus memenuhi kebutuhan rohani dan jasmani kepada yang memerlukan. Tugas gereja bukan sekedar mengajar firman Tuhan, namun juga memberi memberi perhatian kepada jemaat dan orang-orang yang belum percaya secara jasmani (hal fisik). Salah satu perhatian yang perlu diberikan adalah pemenuhan hak aksesibel bagi para penyandang disabilitas. Tujuan penelitian ini adalah menggali pemahaman dan kontribusi Gereja Baptis di wilayah Semarang Barat berkaitan dengan pemenuhan hak penyandang disabilitas. Jenis penelitian ini adalah kualitatif dengan menggunakan instrumen wawancara dan observasi. Hasil yang didapat pimpinan gereja memandang penyandang disabilitas sebagai pribadi yang memiliki kekurangan dan ketidaklengkapan dalam tubuh, sebagai penyandang cacat permanen yang memiliki kebutuhan khusus serta butuh akan perhatian dibanding dengan orang normal pada umumnya. Keterlibatan penyandang disabilitas untuk melayani Tuhan dalam persekutuan orang percaya bukan menjadi hal yang wajib. Kontribusi yang diberikan gereja hanya sampai tahap charity yaitu memberi bantuan sembako, pelayanan kunjungan, pelayanan antar jemput ke tempat ibadah, dan program jaminan kematian. Aksesibilitas fisik di gereja rata-rata berupa ramp dengan kemiringan yang terlalu tajam, pegangan tangga untuk tangga yang terlalu tinggi, dan closet duduk yang dapat menolong disabilitas fisik lebih nyaman.

Kata Kunci: disabilitas; gereja; kontribusi; pemahaman 


\section{PENDAHULUAN}

Negara Kesatuan Republik Indonesia adalah negara yang ingin mewujudkan keadilan sosial bagi seluruh rakyat Indonesia. Hal ini tertulis jelas di dalam alinea keempat Pembukaan Undang-Undang Dasar Negara Republik Indonesia Tahun 1945. Aristoteles (dikutip dalam Sumaryono, 2002) menyebutkan bahwa "keadilan" adalah gagasan yang ambigu, dikarenakan dari satu sisi, konsep "keadilan" mengacu pada keseluruhan kebajikan sosial (kebajikan pada hubungan dengan sesama/tetangga); dan pada sisi yang lain mengacu kepada kebajikan sosial khusus. Sisi pertama disebut "keadilan universal" dan yang kedua disebut "keadilan partikular". Keadilan universal adalah keadilan yang terbentuk bersamaan dengan perumusan hukum. Dan keadilan partikular adalah keadilan yang diidentikkan dengan "kejujuran". Thomas (dikutip dalam Sumaryono, 2002) mengatakan bahwa keadilan universal sebagai iustitia ad alterum, yang berarti salah satu bentuk kebajikan yang menuntun manusia dalam berhubungan dengan sesamanya. Seseorang dikatakan "adil" jika ia mengenali dan mengakui sesamanya sebagai "yang benar-benar berbeda" dari dirinya. Suatu hukum hanya akan berlaku sah jika hukum tersebut sesuai dengan pola-pola keinginan dan cita-cita manusia yang terkandung di dalam realitas kodrat manusia. Ajaran Thomas tentang hukum kodrat ini dijadikan dasar pemikiran tentang hukum yang adil, yang mengikat subjek dalam kesadarannya, yang berarti bahwa setiap hukum hanya akan valid jika dapat memerintah hal-hal yang dihalalkan oleh moral. Oleh karena itu dalam menciptakan kebaikan dan kesejahteraan umum, maka pemberlakukan hukum tidak boleh bertentangan dengan pelaksanaan hakhak manusia (Sumaryono, 2002).

Bangsa Indonesia sebagai bagian dari umat manusia memiliki gagasan tentang dasar negara yang yang disebut Pancasila serta memiliki sebuah Undang-undang Dasar yang disebut UUD 1945. Disana tertuang aturan tentang hak asasi bagi setiap warga negara. Kewarganegaraan seseorang pun diatur dalam sebuah UU. Seseorang disebut sebagai warga negara Indonesia diatur dalam UU No 12 Tahun 2006 tentang Kewarganegaraan Republik Indonesia. Dapat disimpulkan, seseorang disebut Warga Negara Indonesia adalah seseorang yang sebelum UU No 12 Tahun 2006 ini berlaku telah menjadi warga negara Indonesia dan seorang anak yang lahir di wilayah NKRI dengan segala persyaratan yang berhubungan dengan hukum perkawinan dan hukum teritorial. Di dalam peraturan perundangan ini tidak mengatur kewarganegaraan seseorang yang berhubungan dengan suatu kondisi fisik yang dialami oleh seorang anak yang lahir, entah itu mengalami kecacatan atau penyakit bawaan.

Berdasarkan UU No 12 Tahun 2006 tentang Kewarganegaraan Republik Indonesia, maka jika terdapat suatu kasus kelainan pada bayi yang lahir membawa cacat bawaan, maka bukan suatu alasan untuk tidak menerima mereka sebagai bagian dari warga negara Indonesia. Seorang disabilitas sesuai dengan UU RI No 8 Tahun 2016 adalah seseorang yang mengalami keterbatasan fisik, intelektual, mental, dan sensorik dalam jangka waktu yang lama yang dalam berinteraksi dengan lingkungan mengalami hambatan dan kesulitan. Penyandang disabilitas juga merupakan warga negara Republik Indonesia. Oleh karena itu negara menjamin potensi, harkat, dan martabat mereka sesuai dengan hak asasi manusia.

Di Setiap bidang kehidupan, merujuk peraturan perundangan tentang penyandang disabilitas, seharusnya seorang penyandang disabilitas menerima pemenuhan hak yang berdasarkan asas: penghormatan terhadap martabat, otonomi individu, tanpa diskriminasi, partisipasi penuh, keragaman manusia dan kemanusiaan, kesamaan kesempatan, kesetaraan, aksesibilitas, kapasitas yang terus berkembang dan identitas anak, inklusif, dan perlakukan khusus dan perlindungan lebih.

Sebagaimana Yesus datang ke dunia untuk mengajar dan memberitakan Injil Kerajaan 
Allah serta melenyapkan segala penyakit dan kelemahan di antara bangsa. Hal ini membuktikan bahwa Yesus memberlakukan prinsip adil dan memenuhi hak asasi manusia, Yesus memenuhi kebutuhan rohani dan jasmani kepada setiap orang yang mengikuti dan memerlukan Dia. Gereja sebagai kumpulan orang percaya, yang tinggal di wilayah NKRI memiliki tugas dan fungsi yang bersifat holistik. Gereja bukan sekedar mengajar firman Tuhan, namun juga menunjukkan bukti nyata dengan memberikan perhatian secara jasmani atau pemenuhan kebutuhan fisik kepada jemaat dan orangorang yang belum percaya.

Disabilitas menjadi isu yang belum digarap secara sistematis dalam kehidupan bergereja. Gereja sebagai wakil Allah di dunia seharusnya tidak sekedar charity, yang mengandung arti membantu orang lain dengan tujuan derma, kebajikan, dan amal semata, namun lebih dari pada itu perhatian perlu diberikan dengan mengetahui hak-hak penyandang disabilitas secara holistik dalam keberadaannya sebagai manusia yang bermartabat.

Suhendar mengatakan bahwa hanya ada satu gedung gereja di Bandung yaitu Gereja Caritas yang dapat diakses oleh kelompok difabel. Dari minimnya informasi tentang keterlibatan gereja dalam memenuhi hak-hak penyandang disabilitas, maka peneliti berusaha melakukan penelitian kepada gerejagereja Baptis di Semarang Barat. Dari hasil penelitian awal didapatkan bahwa rata-rata gereja Baptis memiliki anggota jemaat yang berusia 60 tahun keatas. Diantaranya merupakan kelompok penyandang penyandang disabilitas baru. Selain itu juga terdapat anggota gereja yang mengalami disabilitas netra.

Berdasarkan latar belakang tersebut maka pada penelitian ini, rumusan masalah yang dikemukakan adalah bagaimana pemahaman dan kontribusi gereja-gereja Baptis di Semarang Barat dalam pemenuhan hak penyandang disabilitas. Tujuan dari penelitian ini adalah untuk mengetahui pemahaman gereja-gereja Baptis di wilayah Semarang Barat tentang hak-hak penyandang disabilitas dalam kaitannya dengan kehidupan bergereja serta bagaimana kontribusi gereja dalam memenuhi kebutuhan mereka. Adapun manfaat penelitian ini, secara akademis dapat memberi kontribusi keilmuan pada kajian tentang hak disabilitas dalam lingkup bergereja, dan secara praktis bermanfaat untuk memperoleh data mengenai pemahaman dan kontribusi gereja Baptis Semarang Barat dalam pemenuhan hak disabilitas, sehingga dapat digunakan gereja sebagai bahan pengambil kebijakan dalam memikirkan program pelayanan yang ramah disabilitas.

\section{METODE PENELITIAN}

Penelitian ini merupakan penelitian kualitatif dengan metode survey kepada gereja-gereja Baptis di Semarang Barat. Populasi penelitian adalah Gembala Sidang atau Pengurus Gereja yang terdiri dari dua belas orang. Teknik pengumpulan data dilakukan dengan wawancara secara langsung dan telepon, serta observasi langsung keadaan bangunan gereja. Validasi instrumen menggunakan validitas konstruk yang merujuk pada kajian teori yang relevan dengan permasalahan penelitian. Selanjutnya melakukan analisa data wawancara dan data observasi yang sudah terkumpul.

Adapun teknik analisis data dilakukan dengan tahapan sebagai berikut: pertama, analisa data sebelum melakukan penelitian, yaitu dengan melakukan pengamatan terhadap kondisi bangunan gereja dan pengumpulan data penyandang disabilitas. Dari pengamatan awal ditemukan, duabelas Gereja Baptis Indonesia di Semarang Barat memiliki anggota jemaat yang masuk dalam kategori penyandang disabilitas fisik dan sensorik. Kedua, analisa setelah kegiatan lapangan. Pada tahap ini, peneliti melakukan reduksi atas data wawancara dan observasi yang sudah terkumpul dengan cara merangkum setiap jawaban dari pertanyaan-pertanyaan yang diajukan kepada responden. Ketiga, tahap display data. Pada tahap ini peneliti menyajikan data dalam bentuk uraian atas temuan. Keempat, tahap penarikan 
kesimpulan, yaitu menyimpulkan temuan baru.

\section{STUDI PUSTAKA}

\section{Pemahaman dan Kontribusi}

Pemahaman berasal dari kata understanding, yang berarti pengertian (Sumarno, 1987). Dalam KBBI "pemahaman" berarti pengertian, pengetahuan banyak, pendapat atau pikiran yang tidak bersesuaian dengan kebanyakan orang, mengerti benar tentang suatu hal.

Kontribusi berasal dari Bahasa Inggris yaitu, contribute yang memiliki makna sebagai keikutsertaan, keterlibatan diri atau sumbangan. Kontribusi juga berarti pemberian andil setiap kegiatan, peranan, masukan, ide dan lainnya (Guritno, 1992). Dengan kata lain kontribusi merupakan keterlibatan yang dilakukan oleh individu atau lembaga yang kemudian memposisikan dirinya melakukan peran dalam sebuah kerjasama, sehingga memberi dampak nilai dari aspek sosial maupun ekonomis (Al Susanti, 2015). Bentuk kontribusi yang dilakukan seseorang atau sebuah institusi dapat berupa pemikiran, kepemimpinan, profesionalisme, finansial, dan sebagainya ( $\mathrm{F}$. Nur, 2014).

\section{Penyandang Disabilitas Pengertian Penyandang Disabilitas}

Sebelum dikeluarkan istilah "penyandang disabilitas", istilah yang lebih populer di tengah-tengah masyarakat adalah "penyandang cacat". Istilah "penyandang cacat" merupakan istilah yang digulirkan UU Nomor 4 Tahun 1997. Kata "cacat" berarti mencakup hal-hal sebagai berikut: kekurangan yang menyebabkan mutunya kurang baik atau kurang sempurna (yang terdapat pada badan, benda, batin atau akhlak); cela atau aib; tidak/kurang sempurna. Istilah "penyandang cacat" cenderung membentuk opini masyarakat bahwa kecacatan itu merupakan hal yang patut dikasihani, sesuatu yang malang, bahkan sampai pada pengertian tidak terhormat dan tidak bermartabat.
Didi Tarsidi dalam the International Classification of Impairment, Disability and Handicap, Kesehatan Dunia (WHO, 1980) mendefinisikan tiga aspek kecacatan, antara lain: impairment adalah kehilangan atau abnormalitas struktur atau fungsi psikologis, fisiologis, atau anatomis; disability adalah suatu keterbatasan atau kehilangan kemampuan yang (diakibatkan oleh suatu impairment) untuk melakukan suatu kegiatan dengan cara atau dalam batas-batas yang dipandang normal bagi manusia: dan handicap adalah suatu kerugian bagi seorang individu, sebagai akibat dari suatu impairment atau disability, yang membatasi atau menghambat terlaksananya suatu peran yang normal, tergantung pada usia, jenis kelamin, faktor sosial budaya (Tarsidi, 2015).

Didi memberikan pendapatnya bahwa Istilah yang lebih tepat digunakan untuk memperhalus istilah "penyandang cacat" adalah istilah yang dapat memenuhi kriteria: deskripsi realistis, tidak mengandung unsur perendahan martabat, menggunakan Bahasa Indonesia, dan sudah cukup familiar bagi sebagian masyarakat Indonesia. Jadi istilah yang tepat dan yang dapat memenuhi kriteria alternatif tersebut adalah "penyandang ketunaan". Istilah ini sesuai dengan pengertian dalam Bahasa inggrisnya yang menyebut kelompok ini dengan sebutan "persons with disabilities".

Dalam UU RI No 8 Tahun 2016 pengertian penyandang disabilitas adalah setiap orang yang mengalami keterbatasan fisik, intelektual, mental, dan/atau sensori dalam jangka waktu lama yang dalam berinteraksi dengan lingkungan dapat mengalami hambatan dan kesulitan untuk berpartisipasi secara penuh dan efektif dengan warga negara lainnya berdasarkan kesamaan hak. Dapat dikatakan pula bahwa disabilitas merupakan suatu ketidakmampuan tubuh dalam melakukan suatu aktivitas atau kegiatan tertentu sebagaimana orang pada umumnya yang disebabkan oleh kondisi ketidakmampuan dalam hal fisiologis, psikologis, dan kelainan struktur atau fungsi anatomi. Dari pengertian di atas, maka ragam penyandang disabilitas dapat dibagi menjadi 
empat golongan, yaitu: penyandang disabilitas fisik; penyandang disabilitas intelektual; penyandang disabilitas mental; dan penyandang disabilitas sensorik.

Disabilitas fisik, adalah gangguan pada tubuh yang membatasi fungsi fisik pada satu bagian anggota tubuh atau lebih atau kemampuan motorik seseorang, diantaranya: gangguan anggota tubuh; gangguan fungsi tubuh akibat spina bifida (cacat lahir yang ditandai dengan terbentuknya celah atau defek pada tulang belakang dan saraf tulang belakang bayi); gangguan fungsi tubuh akibat cerebral palsy (kelainan neurologis yang mempengaruhi saraf motorik untuk pergerakan tubuh); gangguan fungsi tubuh akibat spinal cord injury (cedera tulang belakang); gangguan fungsi tubuh akibat amputasi. Termasuk didalamnya adalah seseorang yang memiliki gangguan yang membatasi sisi lain dari kehidupan sehari-hari, sebagai contoh gangguan epilepsi dan gangguan pernapasan.

Disabilitas intelektual, adalah gangguan keterbatasan yang dapat muncul pada seseorang dengan usia berapapun. Disabilitas intelektual memiliki pengertian yang mencakup berbagai kekurangan intelektual. Seseorang disabilitas intelektual mengalami keterbatasan fungsi pikir atau fungsi adaptif karena tingkat kecerdasannya berada di bawah rata-rata dalam jangka waktu yang lama. Oleh karena itu dalam berinteraksi dengan lingkungan dan sikap dalam masyarakat sering menemui hambatan yang mengakibatkan sulitnya untuk berpartisipasi secara penuh dan efektif berdasarkan kesamaan hak.

Disabilitas mental, sering dikenakan pada seseorang yang memiliki kemampuan intelektual di bawah rata-rata. Selain itu, istilah ini juga digunakan pada seseorang yang mengalami kondisi gangguan emosional dan mental. Pada situasi tertentu saat disabilitas mental mengganggu kinerja aktivitas hidup seperti mengganggu komunikasi, belajar, bekerja dan sebagainya secara signifikan, maka kondisi tersebut disebut sebagai gangguan kejiwaan.
Disabilitas sensorik, adalah gangguan yang terjadi pada indera. Istilah ini digunakan pada penyandang disabilitas netra, disabilitas rungu dan disabilitas wicara. Seseorang digolongkan sebagai disabilitas netra adalah jika seseorang tersebut tidak dapat melihat sama sekali dan mereka yang masih memiliki penglihatan tetapi tidak mampu membaca tulisan biasa berukuran 12 point dalam keadaan cahaya normal dan dari jarak yang normal. Disabilitas rungu disebabkan karena adanya kerusakan alat atau organ pendengaran yang menyebabkan hilangnya kemampuan untuk menerima atau menangkap bunyi. Sedangkan disabilitas wicara berhubungan dengan hilangnya kemampuan berbahasa, mengucapkan kata-kata ketepatan dan kecepatan berbicara serta produksi suara.

Munoz Mendonca (dikutip dalam Cheta Nilawati, 2017) mengatakan bahwa keterbatasan gerak yang dialami oleh orang lanjut usia yang dikarenakan kurangnya protein dalam tubuh berpotensi menjadikan mereka menjadi disabilitas baru. Dengan demikian pada saat orang lanjut usia mengalami keterbatasan gerak dan menghambat aktivitasnya, maka bisa dikatakan bahwa mereka dikategorikan sebagai penyandang disabilitas.

\section{Hak Penyandang Disabilitas}

Negara Kesatuan Republik Indonesia menjamin sepenuhnya kelangsungan hidup setiap warganya. Penyandang disabilitas juga memiliki kedudukan hukum dan hak asasi manusia yang sama sebagai warga negara. Hal ini telah diatur di dalam UU No 39 Tahun 1999 tentang Hak Asasi Manusia, yaitu hak yang bersifat fundamental, sehingga keberadaanya merupakan suatu keharusan, tidak dapat diganggu gugat, bahkan harus dilindungi, dihormati dan dipertahankan dari segala macam ancaman, hambatan dan gangguan dari pihak lain (Sodikin, 2013).

Data Kementerian PPN/Bappenas pada tahun 2017 , terdapat 8,56 persen atau sejumlah 21 juta penduduk Indonesia merupakan penyandang disabilitas serta merupakan kelompok yang memiliki keterbatasan dalam berbagai sektor 
kehidupan. Sektor kehidupan tersebut menyangkut, sektor pendidikan, sektor lapangan kerja, sektor kesehatan, sektor politik dan pemerintahan, sektor kebudayaan dan kepariwisataan, serta sektor pemanfaatan teknologi informasi dan komunikasi.

UU Nomor 4 Tahun 1997 tentang Penyandang Cacat belum dapat mengakomodir pemenuhan hak penyandang disabilitas. UU tersebut lebih bersifat belas kasihan dan usaha untuk memberikan pemenuhan hak kepada mereka hanya bersifat jaminan sosial, rehabilitasi sosial, bantuan sosial, dan peningkatan kesejahteraan sosial. Sedangkan dalam rangka pemenuhan hak asasi manusia seutuhnya belum mendapat perhatian sepenuhnya. Penyandang disabilitas seharusnya juga mendapat kesempatan yang sama dalam upaya pengembangan diri melalui kemandirian sebagai manusia yang bermartabat. Oleh karena hal tersebut, maka perlu dilakukan rekonstruksi peraturan perundangan yang dapat mewujudkan kesamaan hak dan kesempatan bagi penyandang disabilitas menuju kehidupan yang sejahtera, mandiri, dan tanpa diskriminasi dalam pelaksanaannya. Maka pada tahun 2016 tersusunlah UU No 8 Tahun 2016 Tentang Penyandang Disabilitas.

Sesuai Keputusan Presiden No. 9 Tahun 2018, Kementerian PPN/Bappenas yang diimplementasikan oleh GIZ melalui Program Perlindungan Sosial dan Panitia Antar Kementerian menyelenggarakan Diskusi Terfokus Finalisasi RPP Perencanaan dan Rencana Induk Pembangunan Inklusif Disabilitas (RIPID). Dalam perkembangannya, Konsep RPP dan RIPID telah disusun dan menghasilkan pemetaan yang menunjukkan 15 (lima belas) substansi pemenuhan dan penghormatan hak penyandang disabilitas. Dimana hal ini perlu diatur ke dalam sebuah Peraturan Pemerintah. Selanjutnya aturan turunan UU No 8 Tahun 2016 tentang Penyandang Disabilitas akan disederhanakan menjadi delapan RPP yang terdiri dari: 1) akomodasi layak dalam peradilan; 2) akomodasi layak bagi peserta didik penyandang disabilitas; 3) unit layanan disabilitas dan kesejahteraan sosial; 4) habilitasi dan rehabilitasi sosial; 5) pemukiman dan pelayanan publik; 6) insentif dan konsesi; 7) perencanaan, penyelenggaraan, dan evaluasi penghormatan dan perlindungan; 8) pemenuhan hak penyandang disabilitas.

Salah satu tujuan pelaksanaan dan pemenuhan hak penyandang disabilitas sesuai UU RI No 8 Tahun 2016 adalah memastikan pelaksanaan upaya penghormatan, pemajuan, perlindungan dan pemenuhan hak penyandang disabilitas untuk mengembangkan diri serta mendayagunakan seluruh kemampuan sesuai bakat dan minat yang dimiliki untuk menikmati, berperan serta berkontribusi secara optimal, aman, leluasa, dan bermartabat dalam segala aspek kehidupan berbangsa, bernegara, dan bermasyarakat. Hal ini merupakan upaya dan langkah maju untuk memberikan hak penyandang disabilitas secara utuh.

Adapun hak-hak yang semestinya diperoleh dan diperjuangkan oleh kaum disabilitas adalah hak: hidup; bebas dari stigma; privasi; keadilan dan perlindungan hukum; pendidikan; pekerjaan kewirausahaan, dan koperasi; kesehatan; politik; keagamaan; keolahragaan; kebudayaan dan pariwisata; kesejahteraan sosial; aksesibilitas; pelayanan publik; perlindungan dari bencana; habilitasi dan rehabilitasi; konsesi; pendataan; hidup secara mandiri dan dilibatkan dalam masyarakat; berekspresi, berkomunikasi, dan memperoleh informasi; berpindah tempat dan kewarganegaraan; dan bebas dari tindakan diskriminasi, penelantaran, penyiksaan, dan eksploitasi.

Saat ini berbagai lembaga sosial masyarakat bagi kelompok penyandang disabilitas dan pemerintah terus berupaya menggalakkan isu disabilitas sebagai bagian yang harus menjadi perhatian khusus. Dalam rangka menuju Indonesia yang ramah disabilitas, maka pemerintah berusaha mengkampanyekan ramah disabilitas dengan membangun infrastruktur yang ramah disabilitas baik berupa gedung maupun jalan raya. Kementerian Sosial Republik Indonesia pun terus melakukan langkah maju mengajak 
masyarakat menuju masyarakat inklusif. Masyarakat inklusif sendiri adalah masyarakat yang mampu menerima berbagai bentuk keberagaman serta mengakomodasikannya ke dalam berbagai tatanan manupun infrastruktur yang terdapat dalam masyarakat.

Pasal 14 UU RI No 8 Tahun 2016, berbicara mengenai hak disabilitas dalam bidang keagamaan. Adapun penyandang disabilitas berhak: memeluk agama dan kepercayaannya serta beribadat menurut agama dan kepercayaannya tersebut; memperoleh kemudahan akses dalam memanfaatkan tempat peribadatan; mendapatkan kitab suci dan lektur keagamaan lainnya yang mudah diakses berdasarkan kebutuhannya; mendapatkan pelayanan sesuai dengan kebutuhan pada saat menjalankan ibadat menurut agama dan kepercayaannya; dan berhak berperan aktif dalam organisasi keagamaan. Dengan demikian pihak-pihak yang terkait dalam penyelenggaraan pendidikan keagamaan harus turut berpartisipasi dan berkontribusi dalam memberikan pemenuhan hak-hak penyandang disabilitas.

\section{Hakekat Gereja Pengertian Gereja}

Kata gereja dalam Bahasa Indonesia berasal dari kata serapan Bahasa Portugis yaitu "igreja". Dalam Bahasa Portugis merupakan kata serapan yang diambil dari Bahasa Latin. Dalam Bahasa Latin diserap pula dari Bahasa Yunani yaitu "ekklesia". Kata "ekklesia" berarti dipanggil keluar ( $e k=$ keluar; dan kaleo = memanggil). Dengan demikian ekklesia berarti kumpulan orangorang yang dipanggil keluar (dari dunia ini) untuk dapat memuliakan nama Allah.

John Stott (2010) mengatakan bahwa gereja adalah jemaat, merupakan suatu perhimpunan orang-orang yang memperlihatkan eksistensi, solidaritas, yang memiliki satu berbeda dari perhimpunanperhimpunan lain, yaitu "panggilan Allah". Stott mengemukakan bahwa umat Allah, atau "ekklesia"-Nya yang telah dipanggil keluar dari dunia ini untuk menjadi milik kepunyaanNya, dan eksis sebagai entitas yang sungguh- sungguh ada dan terpisah semata-mata hanya karena panggilan-Nya. Di dalam Perjanjian Baru menekankan bahwa Allah yang telah memanggil umat-Nya "kepada suatu persekutuan dengan Anak-Nya, Yesus Kristus" memanggil umat-Nya "menjadi milik Kristus" (Roma 1:6; 1 Korintus 1:9). Dalam 2 Timotius 1:9, menjelaskan bahwa panggilan ini adalah "panggilan kudus" sehingga sebagai orang-orang yang telah dipanggil dengan panggilan kudus harus berpadanan dengan "kehidupan yang kudus" (1 Petrus 1:15-16; Efesus 4:1). Oleh karena kuasa penyucian dari Roh Kudus maka umat-Nya dapat berubah di dalam karakter dan tingkah laku sesuai dengan status baru tersebut, yakni sebagai "orang-orang kudus" yang berbeda, terpisah, yang disebut umat yang dikuduskan bagi Allah. Hal ini senada dengan pendapat Paul Hidayat yang memberi kesimpulan bahwa gereja memiliki karakteristik kehidupan yang kudus, am, apostolik dan misioner. Pengertian "kudus" adalah umat yang khusus ada di dalam Kristus dan karya-Nya telah dikuduskan; "am" berarti sifat universal gereja yang merangkul seluruh umat tebusan dari mulai zaman Perjanjian Lama, Perjanjian Baru, sampai kedatangan Kristus kedua kali; "apostolik" berarti dibangun atas Alkitab dan dipanggil untuk mempertahankan sifat Alkitab; "misioner" berarti bertugas sebagai utusan Kristus yang bersaksi tentang Kristus kepada dunia (Hidayat, 1989).

\section{Pelayanan Diakonia Gereja}

Gereja tidak bisa menarik diri dari perkembangan dunia modern yang penuh dengan persoalan kehidupan dan kemasyarakatan. Newbigin dalam John Stott mengemukakan bahwa "Gereja tidak mungkin dimengerti secara tepat kecuali di dalam suatu sudut pandang missioner dan eskatologis sekaligus" (Stott, 2010). Sesuai dengan Rasul Petrus yang menulis dalam suratnya "Kamulah bangsa yang terpilih, umat yang rajani, bangsa yang kudus, umat kepunyaan Allah sendiri, supaya kamu memberitakan perbuatan-perbuatan yang besar dari Dia, yang telah memanggil kamu keluar dari 
kegelapan kepada terang-Nya yang ajaib.” (1 Petrus 2:9) (Newbigin, 1954). Demikianlah misi bagi orang percaya adalah menyampaikan tentang kebenaran di dalam Yesus dan kerajaan surga-Nya, namun juga menyampaikan perbuatan besar Yesus di dunia dalam kaitannya dalam memenuhi kebutuhan keselamatan kekal dan juga keselamatan dan pemeliharaan selama umat manusia berada di dunia ini. Yesus memberikan keseimbangan yang menjadi contoh bagi gereja dalam melaksanakan tugasnya di dunia ini.

Di dalam pengajaran-Nya, Yesus sering memberikan kiasan-kiasan tentang gambaran Allah dan umat yang memiliki hubungan yang sangat erat (Stott, 2010). Allah digambarkan sebagai seorang Suami, Pemilik Kebun, Gembala, Raja, Bapa, Pembuat Bangunan, dan Kepala tubuh. Sedangkan umat-Nya digambarkan sebagai pengantinNya, orang-orang upahan, domba-dombaNya, keluarga-Nya, dan tubuh-Nya. Dalam peranannya sebagai anggota tubuh Kristus, orang-orang Kristen memiliki tugas dan fungsi masing-masing sesuai dengan talenta yang dimilikinya. Gambaran tentang kiasankiasan tersebut memberi pengertian bahwa Allah memberikan tanggung jawab kepada umatnya untuk melakukan tugas yang penting. Segala tanggung jawab yang dipercayakan Allah telah dipercayakan kepada "gerejaNya". Tanggung jawab tersebut termuat dalam 1 Petrus 2:5-10, yang menjelaskan bahwa umat Allah adalah imamat kudus, yang diciptakan untuk mempersembahkan kepadaNya persembahan-persembahan yang rohani dan yang berkenan kepada-Nya berupa pujipujian dan doa, selain itu umat Allah diciptakan untuk tujuan memberitakan perbuatan-perbuatan yang besar dari Allah. Kesimpulannya adalah, umat Allah memiliki tujuan untuk menjadi persekutuan orangorang yang beribadah kepada Tuhan Yesus dan menyaksikan kemuliaan dan kebesaranNya.

Tujuan umat Allah di tengah dunia ini begitu jelas. Gereja sebagai bagian dari masyarakat tidak bisa bisu dan buta dalam menghadapi kenyataan yang ada disekitarnya.
Gereja perlu memiliki sikap atas pergumulan umat dan masyarakat. Gereja adalah persekutuan yang dinamis yang memberikan visinya dalam memperkuat dan mengarahkan manusia untuk membangun dunia yang sejahtera dan berkeadilan sosial dalam segala aspek kehidupan.

Disabilitas telah berimplikasi pada identitas diri, identitas komunal, dan identitas teologis. Gereja dan komunitas Kristen tidak jarang secara sengaja maupun tidak sengaja telah menganggap disabilitas tidak exis di dalam gereja dan tidak menganggap mereka sebagai bagian dari jemaat. Roy Soselisa dalam opininya, mengatakan bahwa gereja dalam budaya masa kini ada yang memiliki anggapan, kaum disabilitas adalah objek yang harus "disembuhkan" sebagai orang yang terkena dosa turunan dari orang tua yang berdosa, terkutuk, dan kerasukan setan. Sehingga gereja perlu mengadakan program "mujizat kesembuhan" bagi penyandang disabilitas (Soselisa, 2018). Penyandang disabilitas dilihat sebagai symbol dari dosa yang harus dihindari, tanda keterbatasan Allah yang perlu direnungkan, atau personifikasi dari penderitaan yang harus dikasihi (Creaner, 2009).

Paulus menggunakan metafora tubuh Kristus untuk menggambarkan jemaat di Korintus. Setiap anggota tubuh Kristus adalah "anugerah", dan tidak ada anugerah yang pantas untuk tertekan, terhilang, maupun dikucilkan (Amos Yong, 88) (Yong, 2010). Pandangan ini menjelaskan, bahwa penyandang disabilitas merupakan bagian dari anggota tubuh Kristus. Setiap anggota tubuh Kristus memiliki peran masing-masing, termasuk penyandang disabilitas juga memiliki kontribusi bagi pertumbuhan tubuh Kristus dan memiliki hak dalam melayani Tuhan di dalam komunitas persekutuan.

Penelitian Novriana Gloria (dikutip dalam Debora Beth Creamer, 2009) menyatakan, disabilitas merupakan "open minority" yang dapat diikuti siapa saja dan kapan saja. orang "able" sebenarnya adalah orang yang "temporary-abled" yaitu, pada akhirnya semua orang akan menjadi disable (Hutagalung, 2018). Bisa dikatakan bahwa 
setiap orang bisa saja mengalami kejadian yang menyebabkan dirinya mengalami disabilitas. Oleh karena itu perenungan atas penghargaan terhadap hak-hak disabilitas perlu direfleksikan dalam bentuk nyata dan terukur.

\section{Gereja Baptis dan Disabilitas}

Gereja Baptis Indonesia memiliki suatu tata laksana pejabat gereja. Salah satu bab dalam tata laksana pelayanan yang harus dilakukan seorang gembala sidang adalah "memahami jemaat". Pengertian "memahami jemaat" disini adalah dengan: Pertama, mengenal macam kepribadian. Departemen Kependetaan GGBI memberi kesimpulan bahwa maksud dari frasa "mengenal macam kepribadian" mengacu kepada pengenalan akan sifat-sifat jemaat menurut beberapa pandangan para filsuf, diantaranya adalah Hipocrates, yang mengkategorikan sifat manusia menjadi beberapa sifat yaitu sifat kolerik, sanguin, melankolis, dan plegmatik. Selain itu juga mengacu kepada pandangan Carl Jung, yang mengkategorikan sifat manusia dengan kategori introvert, ambivert, dan ekstrovert. Disamping pengenalan kepada jemaat atas kategori sifat, gembala sidang juga harus memahami bahwa seorang jemaat adalah seorang pribadi yang memiliki keinginan, kemauan, cita-cita dan pengharapan (Ngatimin, 2017). Kedua, memahami tugas perkembangan hidup dari jemaat. Dalam hal ini Departemen Kependetaan GGBI mengklasifikasikan tugas perkembangan seorang jemaat dilihat dari kategori usianya. Disamping itu, makna dari memahami tugas perkembangan jemaat adalah dengan memahami kondisi jemaat yang sedang dalam keadaan mengalami penurunan kesehatan.

Pada BAB 4 pasal 1 No 5 buku tata laksana pejabat gereja, mengatakan bahwa gembala sidang berkewajiban memberikan penyuluhan secara teratur dan melakukan kunjungan kepada anggota yang mempunyai kebutuhan khusus. Definisi dari frasa "jemaat yang memiliki kebutuhan khusus" adalah seseorang yang dalam keadaan sakit, berduka cita, sedang melawan dosa dan pencobaan, undur, kurang setia, dan jemaat yang belum memakai karunianya (Ngatimin, 2017).

Dengan demikian, dapat disimpulkan bahwa makna frasa "memahami jemaat" dalam konteks tata laksana pejabat gereja Baptis hanya terbatas pada pengertian memahami jemaat dengan memperhatikan sisi sifat, keinginan, cita-cita, pengharapan, dan kondisi fisik yang disebabkan karena penurunan kesehatan. Belum masuk kepada usaha untuk memahami seorang jemaat yang mengalami gangguan disabilitas, baik yang mengalami disabilitas sejak lahir, ataupun akibat dari proses kehidupan yang dijalani oleh jemaat itu sendiri. Sedangkan dalam konteks "memahami" penyandang disabilitas, bukanlah hal yang mudah. Perlu pengetahuan khusus bagi seorang Gembala Sidang untuk masuk dalam ranah memahami komunitas penyandang disabilitas. oleh karena itu, seorang Gembala Sidang harus memiliki keterbukaan untuk belajar lebih lagi tentang isu disabilitas. Sehingga dapat berkontribusi mewujudkan keadilan bagi kaum disabilitas dalam konteks kehidupan bergereja.

\section{Tugas Gereja dalam Pemenuhan Hak Disabilitas}

Pasal 14 UU RI No 8 Tahun 2016 secara khusus berbicara mengenai hak disabilitas dalam bidang keagamaan. Gereja berkewajiban mengerti hak-hak penyandang disabilitas yang berada di lingkunganya. Penyandang disabilitas berhak:

Pertama, Memeluk agama dan kepercayaannya serta beribadat menurut agama dan kepercayaannya tersebut. Hal ini berarti bahwa penyandang disabilitas sesuai dengan instrumen HAM dalam Deklarasi Universal HAM memiliki kebebasan menyatakan agama atau kepercayaannya dengan cara mengajarkan, melakukan, beribadat dan menepati baik secara sendiri maupun secara bersama-sama dengan orang lain (Sodikin, 2013). Dengan demikian gereja berkewajiban menerima setiap penyandang disabilitas dalam segala kondisinya untuk dapat menjalankan ibadah secara sendiri maupun dalam persekutuan dengan jemaat yang lain; 
Kedua, Memperoleh kemudahan akses dalam memanfaatkan tempat peribadatan. Gereja perlu memberi aksesibilitas penyandang disabilitas. Aksesibilitas adalah kemudahan yang disediakan untuk penyandang disabilitas guna mewujudkan kesamaan kesempatan. Kesempatan disini berarti kesempatan untuk turut andil dalam melaksanakan fungsi gereja baik dalam peribadatan secara pribadi maupun bersamasama dengan jemaat lainnya. UU No 28 Tahun 2002, berbicara tentang Bangunan Gedung. Oleh karena gedung gereja merupakan sarana pelayanan publik, maka untuk memberikan hak akses bagi penyandang disabilitas perlu prinsip-prinsip desain universal pelayanan publik yang akses meliputi: kesetaraan penggunaan ruang, keselamatan dan keamanan; kemudahan akses tanpa hambatan; kemudahan akses informasi; kemandirian penggunaan ruang; efisiensi upaya pengguna; kesesuaian ukuran dan ruang secara ergonomis.

Aksesibilitas dapat berupa fisik dan non fisik. Aksesibilitas fisik adalah bangunan gedung gereja. Pada bangunan gereja haruslah menyediakan: 1) akses ke, dari dan dalam bangunan gereja; 2) pintu, tangga, lift khusus untuk bangunan gereja yang bertingkat; 3) ubin tekstur pemandu (guiding block); 4) ramp dengan kemiringan yang sesuai; 5) ruang ibadah yang akses; 6) toilet akses; 7) tempat parkir akses; 8) alarm lampu darurat penyandang disabilitas rungu yang diletakkan pada dinding atas pintu dan lift; 9) fasilitas teletext/running text penyandang disabilitas rungu; 10) papan informasi dengan lampu indikator; 11) anjungan tunai mandiri yang akses; 12) tempat minum; 13) tempat telepon; 14) peringatan darurat; dan 15) tanda-tanda atau signase.

Sedangkan pelayanan non fisik bagi penyandang disabilitas berupa pelayanan informasi dan komunikasi serta pelayanan sensitive disabilitas. Pelayanan informasi dan komunikasi yang dimaksud adalah bentuk pelatihan peningkatan kapasitas dalam bidang teknologi informasi dan akses yang mudah dalam mendapatkan informasi. Sedangkan pelayanan sensitive disabilitas dapat berupa pelatihan bagi jemaat dalam mengembangkan budaya inklusif. Dengan adanya gerakan dari pemerintah yang terus menggalakan budaya inklusif, baik dalam ranah pendidikan, ketenagakerjaan, wisata, dan sebagainya. Maka gereja perlu turut mengembangkan budaya inklusif yang bertujuan mengedepankan konsep keanekaragaman setiap individu. Pelayanan sensitive disabilitas dapat pula berupa pendidikan kepada jemaat tentang bagaimana cara menjalin sosial komunikasi yang tepat kepada penyandang disabilitas, sehingga pernyataan atau bahasa yang digunakan dalam setiap komunikasi tidak menyinggung perasaan mereka.

Ketiga, Mendapatkan kitab suci dan lektur keagamaan lainnya yang mudah diakses berdasarkan kebutuhannya. Fasilitas tersebut berupa buku-buku atau kitab braille, Alkitab audio atau talking scanner untuk disabilitas netra. Bagi penyandang disabilitas rungu, gereja dapat menolong dengan memberi akses Alkitab dalam Bahasa isyarat yang berbentuk Bible Apps.

Keempat, Mendapatkan pelayanan sesuai dengan kebutuhan pada saat menjalankan ibadat menurut agama dan kepercayaannya. Gereja perlu memiliki Pokja studi disabilitas sebagai upaya menjadi gereja yang terbuka bagi siapa saja. Melalui Pokja diharapkan gereja dapat membuat sebuah analisa kebutuhan masing-masing penyandang disabilitas dalam konteks ibadah maupun hubungan sosial sesama jemaat, sehingga gereja dapat memberikan pelayanan yang tepat. Secara umum Earl F. Zeigher (1958) mendaftarkan kebutuhan orang lanjut usia yang bisa jadi merupakan penyandang disabilitas baru dalam proses menjalani masa tuanya, antara lain: kepastian tentang kasih Allah yang berkelanjutan; jaminan bahwa hidupnya dalam perlindungan Tuhan; bebas dari emosi yang memuncak yang dikarenakan rasa bersalah, rasa takut, dan kesedihan, dan kesepian; suatu pandangan hidup menyangkut waktu dan kekekalan; melanjutkan pertumbuhan spiritual melalui pengalaman baru; kepuasan status dalam kehidupan selaku manusia; merasa dibutuhkan dan berguna bagi orang lain. Daftar kebutuhan tersebut dapat 
digunakan oleh gereja dalam memberikan pelayanan yang tepat bagi mereka (Sutanto, 2008).

Kelima, berhak berperan aktif dalam organisasi keagamaan. Penyandang disabilitas belum tentu adalah orang yang tidak memiliki satupun kemampuan diri. Tuhan memberikan talenta untuk dapat dikembangkan, oleh karena itu penyandang disabilitas pun berhak berperan aktif dalam setiap organisasi di gereja dan berhak untuk ambil bagian dalam melayani Tuhan sesuai dengan talenta tersebut.

Alkitab memandang semua orang percaya sebagai satu tubuh tanpa terkecuali (1 Kor. 12:27). Setiap orang termasuk penyandang disabilitas berhak mendapat penghormatan, perhatian dan kasih. Gereja berperan untuk melayani mereka sebagai satu keluarga (Roma 12:4-5; Mark 3:35). Pelayanan yang diberikan kepada penyandang disabilitas harus sampai kepada ranah mengembangkan diri dan mendayagunakan seluruh kemampuan sesuai dengan talenta yang mereka miliki, sehingga Allah dimuliakan dalam segala hal melalui Yesus Kristus (1 Pet 4:10-11).

\section{HASIL DAN PEMBAHASAN Hasil}

Berikut hasil penelitian mengenai pemahaman dan kontribusi Gereja-gereja Baptis Wilayah Semarang Barat tentang hak penyandang disabilitas yang merupakan bagian dari anggota gereja. Dari tiga belas gereja Baptis yang ada di wilayah Semarang Barat, duabelas diantaranya memiliki anggota gereja yang dapat dikategorikan sebagai penyandang disabilitas dengan jumlah total dua puluh satu orang. Kategori disabilitas tersebut antara lain disabilitas fisik sejumlah enam belas orang yang terdiri dari jemaat yang sakit diabetes yang menyebabkan harus dilakukan operasi dan diamputasi bagian kakinya dan manula yang memiliki keterbatasan mobilitas sehingga perlu orang lain untuk menolongnya; disabilitas intelektual sejumlah satu orang; dan disabilitas sensorik sejumlah empat orang yang terdiri dari disabilitas rungu, dan disabilitas netra.

Hasil wawancara secara mendalam terhadap gembala sidang dan pengurus gereja Baptis Indonesia wilayah Semarang Barat yang terdiri dari dua belas orang responden memberikan pemahaman mereka tentang istilah "penyandang disabilitas" sebagai berikut: pendapat dari sebelas responden dapat disimpulkan, "penyandang disabilitas adalah seseorang yang memiliki kekurangan dan ketidaklengkapan dalam tubuh, cacat permanen dan memiliki kebutuhan khusus serta butuh akan perhatian dibanding dengan orang normal pada umumnya. Kekurangan tersebut dapat berupa kekurangan fisik seperti tunadaksa; kekurangan intelektual seperti idiot, autis; kekurangan sensorik seperti tunarungu dan tunanetra; dan cacat mental. Satu orang responden menjelaskan bahwa penyandang disabilitas adalah manusia yang mempunyai kekuatan atau kemampuan lebih dibanding manusia pada umumnya, hal ini disebabkan karena seorang penyandang disabilitas yang tidak memiliki bagian tubuh lengkap seperti orang kebanyakan, terdapat kemungkinan pada bagian tubuh lain memiliki kemampuan yang lebih dibanding dengan orang lain pada umumnya, sehingga dapat melakukan sesuatu yang lebih besar.

Hasil penelitian memperlihatkan Berdasarkan peran serta dalam pelayanan peribadatan, lima orang responden mengatakan, penyandang disabilitas yang ada di gereja tidak berperan dalam pelayanan apapun. Hal ini disebabkan karena seksi ibadah gereja memang tidak memberi jadwal pelayanan kepada mereka. Pada tataran praktis, penyandang disabilitas tidak diberi tawaran untuk mau atau tidak mereka mengambil bagian dalam pelayanan. Sedangkan tujuh responden mengatakan bahwa penyandang disabilitas diberi hak untuk turut ambil bagian dalam pelayanan peribadatan. Pelayanan yang dilakukan berupa pendoa syafaat, pembawa persembahan, penerima tamu, tim kunjungan, pemain musik, pujian vocal group, dan penyampai renungan firman Tuhan. 
Salah satu hak dari penyandang disabilitas adalah hak untuk berperan serta dalam kehidupan berorganisasi. Dari sembilan responden mengatakan, penyandang disabilitas terlibat aktif di dalam organisasi gereja, terutama organisasi wanita dan organisasi musik karawitan yang ada di gereja tersebut. Keterlibatan mereka diwujudkan dalam partisipasi aktif sebagai panitia acaraacara gereja dan kepengurusan di dalam organisasi Wanita Baptis Indonesia. Tiga responden menjelaskan, penyandang disabilitas tidak mampu terlibat dalam organisasi gereja karena keterbatasan kemampuan fisiknya dalam melakukan mobilitas diri.

Dengan membandingkan aksesibilitas yang seharusnya dimiliki oleh bangunan publik sesuai dengan UU No 28 tahun 2002 tentang bangunan gedung maka dari hasil penelitian yang dilakukan dengan melihat bangunan fisik gereja-gereja Baptis Indonesia Wilayah Semarang barat, dapat digambarkan aksesibilitas bangunannya sebagai berikut: 1) Akses ke, dari dan dalam bangunan gereja bervariasi, enam gereja memiliki bangunan yang kontur tanahnya rata dengan jalan. Sedangkan enam bangunan gereja berdiri pada kontur tanah yang tinggi. Oleh karena itu untuk mempermudah masuk ke area gedung disediakan ramp. 2) Pintu yang disediakan pada setiap sisi bangunan gereja, baik yang menuju ruang ibadah, ruang minum, toilet masih standar umum, bukan sejenis pintu otomatis. Bukaan pintu ada yang menuju arah dalam dan ada yang menuju arah luar. Jalan menuju ruang ibadah ada yang berundakundak, ada yang dilengkapi dengan pegangan tangga, tapi tidak semua dilengkapi dengan pegangan tangga. Beberapa gereja yang bertingkat tidak memiliki lift khusus; 3) Pada dua gereja yang memiliki jemaat disabilitas netra dan low vision belum memiliki ubin tekstur pemandu (guiding block); 4) Bangunan gereja yang berdiri pada kontur tanah yang tinggi memiliki ram dengan kemiringan yang terlalu curam, bagi pengguna kursi roda terlalu sulit untuk melewatinya sendirian, butuh orang lain yang mendorong dan menopang; 5) Pada ruang ibadah gereja- gereja Baptis di Semarang Barat bervariasi, sepuluh bangunan gereja memiliki ruang ibadah yang luas dengan bangku yang renggang sehingga memudahkan setiap orang yang akan menggunakan, namun ada juga yang penataan bangku satu dengan bangku lainnya terlalu sempit dikarenakan bangunan gereja yang sempit. Ada satu gedung gereja yang memiliki pilar-pilar di dalamnya, sedangkan gedung gereja tersebut tergolong sempit, sehingga mengganggu jemaat untuk menuju bangku. Dari duabelas gereja yang diteliti, akses menuju mimbar berundakundak dan tidak ada ram, sehingga menyulitkan jemaat disabilitas untuk menuju kesana. Terdapat pula ruang baptisan yang sempit dimiliki oleh beberapa gereja.; 6) Dua bangunan gereja memiliki akses jalan menuju toilet yang mudah dan menggunakan kloset duduk yang memudahkan disabilitas fisik menggunakannya. Sembilan gereja memiliki keterbatasan akses menuju toilet. Jalan menuju toilet jauh, berundak-undak, dan pintu yang sempit, sehingga menyulitkan pengguna kursi roda, juga masih menggunakan kloset jongkok. Keseluruhan gereja tersebut memiliki bentuk ruangan toilet hanya satu kotak persegi yang terdiri dari bak mandi dan kloset, serta cantolan baju. Beberapa bak mandi posisinya terlalu tinggi dari tempat dudukan closet, sehingga mempersulit penyandang disabilitas menjangkau air; 7) Dilihat dari tempat parkir yang dimiliki gereja, didapatkan data, ada empat bangunan gereja yang memiliki lahan parkir untuk kendaraan roda dua, dan hanya muat untuk dua sampai empat mobil, namun juga dengan meminjam lahan penduduk setempat. Gereja yang lain memiliki keterbatasan lahan parkir karena berada di tengah perkampungan; 8) keduabelas gereja tidak terdapat alarm lampu darurat penyandang disabilitas rungu; 9) keduabelas gereja tidak terdapat fasilitas teletext/running text penyandang disabilitas rungu; 10) keduabelas gereja tidak terdapat papan informasi dengan lampu indikator; 11) keduabelas gereja tidak terdapat anjungan tunai mandiri yang akses; 12) Akses menuju ruang minum, didapati empat gereja memiliki tempat minum yang mudah dijangkau; 13) 
keduabelas gereja tidak dilengkapi peringatan darurat; dan 15) keduabelas gereja tidak dilengkapi tanda-tanda atau signase.

Dari hasil penelitian yang melihat seberapa dalam wawasan pendeta mengenai isu disabilitas, ditemukan duabelas responden mengatakan bahwa pendeta belum pernah berkhotbah dengan tema disabilitas, namun hanya sebatas memberi ilustrasi tentang hal kecacatan dalam khotbah. Jemaat juga belum pernah diajar tentang bagaimana mengenal kebutuhan dan bagaimana upaya gereja memberi pemenuhan atas hak-hak penyandang disabilitas di dalam kehidupan bergereja.

Dari beberapa gereja yang memiliki jemaat disabilitas netra atau low vision, gereja tidak memiliki Alkitab atau buku-buku yang dengan huruf braille, juga tidak terdapat fasilitas talking scanner dan bahasa isyarat bible apps.

Usaha gereja memenuhi kebutuhan penyandang disabilitas dalam konteks peribadatan baik secara individu dan komunal, dari sepuluh gereja menjelaskan, bahwa gereja memiliki program sosial berupa: santunan sembako yang diberikan dalam kurun waktu yang berlainan, ada yang satu bulan sekali, dua bulan sekali, satu tahun sekali, dan program temporary; selanjutnya dua gereja memberikan program jaminan kematian kepada orang lanjut usia mulai dari pendaftaran, sampai kepada iuran setiap bulannya; program gereja lainnya adalah kunjungan ke rumah penyandang disabilitas; juga terdapat program antar jemput jemaat yang mengalami disabilitas pada saat melaksanakan ibadah bersama tempat ibadah.

\section{Pembahasan}

Penyandang disabilitas adalah bagian dari warga negara yang memiliki hak-hak dalam seluruh penyelenggaraan kehidupannya. Penyandang disabilitas bisa berada dimana saja, bahkan setiap orang mempunyai resiko menjadi seorang disabilitas. Gereja sebagai kumpulan orangorang percaya perlu menjadi terang dan garam dalam kehidupan, mampu mengaplikasikan tugasnya sebagai pembawa terang dan mengasinkan. Salah satu fungsi gereja adalah pelayanan. Pelayanan kepada kaum disabilitas di gereja menjadi isu yang harus diketahui dan dipahami dengan baik. Dengan demikian gereja dapat memberikan kontribusi secara langsung dalam rangka memberi penghormatan kepada kelompok penyandang disabilitas.

Responden penelitian ini adalah para pimpinan gereja dan para pengurus gereja di gereja-gereja Baptis wilayah Semarang Barat. Seluruhnya berjumlah dua belas orang. Responden adalah pimpinan gereja (Gembala Sidang) dan pengurus gereja dikarenakan mereka memiliki pemahaman yang luas akan situasi dan kondisi di dalam gereja dan segala permasalahannya. Dari penelitian diperoleh data sejumlah dua puluh satu orang masuk dalam kategori penyandang disabilitas tersebar di duabelas Gereja Baptis wilayah Semarang Barat. Penyandang disabilitas tersebut terdiri dari disabilitas fisik, mental dan sensorik.

Dalam penelitian ini diketahui bahwa pemahaman sebagian besar responden mengenai penyandang disabilitas adalah sebagai seseorang yang memiliki kekurangan dan ketidaklengkapan dalam tubuh, penyandang cacat permanen dan memiliki kebutuhan khusus serta butuh akan perhatian dibanding dengan orang normal pada umumnya. Kata "cacat" yang di dalam KBBI berarti mencakup pengertian bahwa seseorang memiliki kekurangan yang menyebabkan mutunya kurang baik atau kurang sempurna (yang terdapat pada badan, benda, batin, atau akhlak); cela;aib. Kata "cacat" sering diasosiasikan dengan atribut-atribut negative. Dedi Tarsidi mengatakan istilah "penyandang cacat" cenderung mengarahkan opini publik bahwa orang-orang dengan kecacatan adalah orang-orang yang malang, patut dikasihani, tidak terhormat, dan tidak bermartabat. Dari hasil penelitian ini sebagian besar pemahaman responden terbatas pada melihat keberbedaan secara fisik yang ada pada diri disabilitas dan diperbandingkan dengan orang-orang pada umumnya. Namun satu responden memberikan pernyataan yang berbeda dengan pandangan responden yang lain. Ia 
menyatakan bahwa penyandang disabilitas adalah manusia yang mempunyai kekuatan atau kemampuan lebih dibanding manusia pada umumnya, hal ini disebabkan karena seorang penyandang disabilitas yang tidak memiliki bagian tubuh lengkap seperti orang kebanyakan, terdapat kemungkinan pada bagian tubuh lain memiliki kemampuan yang lebih dibanding dengan orang lain pada umumnya, sehingga dapat melakukan sesuatu yang lebih besar.

Gereja secara spontan memberi hak bagi penyandang disabilitas untuk dapat berperan dalam pelayanan gereja dan terlibat dalam organisasi yang ada. Gereja juga memberi keleluasaan bagi mereka untuk terlibat dalam kepengurusan suatu kegiatan atau menjadi panitia dalam kegiatan tertentu. Beberapa gereja memberikan kesempatan dengan memberikan jadwal pelayanan. Namun ada pula gereja yang tidak memberikan kesempatan melayani atau menawarkan kepada mereka untuk mau atau tidaknya mereka terlibat dalam pelayanan.

Dari tampilan fisik bangunan gereja, secara umum belum dapat memberikan akses yang nyaman bagi penyandang disabilitas. Pada gereja yang kontur tanahnya naik, akses menuju ruang ibadah didominasi dengan tangga yang tinggi dan ram yang masih curam. Belum semua tangga disertai dengan pegangan tangga. Akses menuju mimbar pada kedua belas gereja masih berupa undakundakan dan tidak terdapat ram. Pintu pada ruang ibadah dan toilet tidak dengan model otomatis, pegangan pintu sudah ada yang menuju luar tetapi ada juga yang masih ke arah dalam. Ruang ibadah sudah didominasi dengan ruang yang luas dan penataan bangku yang renggang yang dapat memudahkan penyandang disabilitas menuju bangku. Namun ada juga gereja yang penataan bangku satu ke bangku yang lain terlalu sempit dikarenakan tidak memiliki bangunan gereja yang luas. ruang toilet didominasi dengan bentuk ruang yang hanya satu kotak persegi yang berisi bak mandi, kloset jongkok dan cantolan baju. Hal ini belum bisa memberikan akses yang nyaman bagi penyandang disabilitas. Untuk tempat parkir, gereja rata- rata belum memiliki lahan sendiri. Gereja masih meminjam lahan parkir pada penduduk setempat.

Sampai saat ini gereja-gereja belum memiliki fasilitas-fasilitas lain yang mendukung sebuah bangunan yang aksesibel, antara lain, belum adanya alarm lampu darurat, teletext/running text untuk disabilitas rungu. Papan informasi dengan lampu indikator, anjungan tunai mandiri yang akses, peringatan darurat, dan signase, Alkitab dalam tulisan braille, talking scanner, bible apps.

Gereja tidak memiliki program secara khusus untuk penyandang disabilitas. Pelayanan diakonia gereja kepada penyandang disabilitas berupa santunan sembako yang diberikan dalam kurun waktu tertentu, pelayanan cek kesehatan, pelayanan antar jemput ke tempat ibadah dan program jaminan kematian.

Bangunan gedung gereja-gereja Baptis di wilayah Semarang Barat rata-rata berada di tengah area penduduk yang padat. Beberapa di pinggir jalan raya, dan beberapa lagi berada di pertengahan kampung. Hal ini menyebabkan gereja tidak bisa memperluas lokasi tempat ibadah dan lahan parkir. Hal ini juga yang menjadi kesulitan bagi gereja untuk memberikan akses yang seluas-luasnya kepada penyandang disabilitas. Solusi untuk memperluas area bangunan gedung gereja adalah dengan membuat gedung bertingkat, namun usaha ini membutuhkan dana yang tidak sedikit, serta kesiapan jemaat dalam merencanakan dan merealisasikan program yang besar tersebut. Dengan demikian hal ini menjadi salah satu hambatan bagi gereja untuk memberikan akses yang lengkap aman dan nyaman bagi penyandang disabilitas.

Dalam hal pengajaran tentang isu disabilitas, gereja sama sekali belum pernah melakukan. Meski ada beberapa pendeta yang menampilkan sisi disabilitas dalam ilustrasi khotbah, namun belum menyangkut pembelajaran kepada jemaat tentang hak-hal disabilitas yang perlu diberikan oleh gereja kepada mereka. Pendidikan tentang hal-hal yang berhubungan dengan penghormatan terhadap disabilitas secara holistik belum dilakukan oleh gereja. 


\section{KESIMPULAN}

Berdasarkan kajian yang telah dipaparkan dapat disimpulkan bahwa sebagian besar pimpinan gereja memandang penyandang disabilitas sebagai pribadi yang memiliki kekurangan dan ketidaklengkapan dalam tubuh, sebagai penyandang cacat permanen dan memiliki kebutuhan khusus serta butuh akan perhatian dibanding dengan orang normal pada umumnya. Sehingga keterlibatan penyandang disabilitas untuk melayani Tuhan dalam persekutuan orang percaya, bukan menjadi hal yang wajib. Gereja cukup memberi keleluasan bagi mereka untuk mau terlibat atau tidak dalam pelayanan, namun tidak sampai kepada tahap membuat mereka mandiri atau memberdayakan mereka dalam konteks pelayanan.

Kontribusi yang diberikan gereja kepada penyandang disabilitas hanya sampai tahap charity yaitu memberi bantuan dalam bentuk sembako, pelayanan kunjungan, pelayanan antar jemput ke tempat ibadah, dan program jaminan kematian. Selain itu pemberian aksesibilitas fisik berupa ramp, baik berupa ramp dengan kemiringan yang sesuai maupun dengan kemiringan yang terlalu tajam, serta pegangan tangga untuk tangga yang terlalu tinggi. Selain itu juga closet duduk yang dapat menolong disabilitas fisik lebih nyaman.

Dari hasil penelitian ini sepenuhnya gereja-gereja Baptis di Semarang Barat belum mempelajari isu disabilitas. Hal-hal yang dilakukan berhubungan dengan pembangunan gedung gereja belum sepenuhnya memberikan akses yang aman dan nyaman bagi penyandang disabilitas. bagi penyandang disabilitas yang ingin menggunakan ruang umum seperti toilet terpaksa harus menunggu sampai ibadah selesai karena terbatasnya kemampuan menuju ke area tersebut.

\section{REKOMENDASI}

Berdasarkan kesimpulan peneliti, maka beberapa hal yang menjadi rekomendasi peneliti adalah:
Gembala Sidang hendaknya berusaha memahami pentingnya isu mengenai hak-hak penyandang disabilitas dalam kaitannya dengan kehidupan beribadah. Hal ini bisa dilakukan dengan mempelajari dan mendalami tentang aturan perundangundangan yang berbicara tentang "penyandang disabilitas".

Kepada Ketua Panitia Perancang atau Pengurus Gereja dapat membuat sebuah penelitian yang mengkaji tentang kebutuhan penyandang disabilitas secara mendalam, demi mewujudkan kesamaan hak dan kesempatan bagi penyandang disabilitas di gereja menuju kehidupan yang sejahtera, mandiri, dan tanpa diskriminasi. Serta membuat program menuju gereja yang ramah disabilitas baik dalam konteks pelayanan maupun aksesibilitas.

Kepada Gabungan Gereja-gereja Baptis Indonesia atau PGI dalam hal ini: 1) Membuat kebijakan yang berkaitan dengan isu disabilitas; 2) Menjalin kerjasama dengan lembaga-lembaga advokasi disabilitas dalam rangka memberikan edukasi kepada jemaat tentang isu disabilitas.

Kepada dinas sosial kota Semarang dapat melakukan edukasi kepada gereja-gereja tentang isu disabilitas.

\section{DAFTAR PUSTAKA}

Creaner, Deborta Beth. (2009). Disability and Christian Theology. Embodied Limits and Constructive Possibilities. New York: Oxford University Press.

Daniel Sutanto, Sekilas Tentang Pelayanan Pastoral di Indonesia, (Jakarta: Majelis Jemaat GKI Menteng, 2008), 115.

Departemen Kependetaan. (2017.)Tata Laksana Pejabat GBI. Jakarta: GGBI.

Guritno,T. (1992) Kamus Ekonomi. Yogyakarta: Gadjah Mada University Press.

Kamus Besar Bahasa Indonesia Edisi Ketiga. (2002). Jakarta: Balai Pustaka. 
Newbigin, Lesslie. (1954). The household of God. Universallirary: Friendship Press.

Penjelasan atas Undang-undang RI No 8 Tahun 2016 Tentang Disabilitas

Sumaryono, E. (2002). Etika Hukum

Relevansi Teori Hukum Kodrat Thomas

Aquinas. Yogyakarta: Kanisius.

UU No 28 tahun 2002, Tentang Bangunan Gedung

UU RI Nomor 8 Tahun 2016 tentang Penyandang Disabilitas

John Stott. "Ekklesia" - Gereja. Sabda. Org.e-Reformed edisi 121(26-5-2010).1

Sodikin, Hukum dan Hak Kebebasan

Beragama..Jurnal Cita Hukum. Vol. I No. 2 Desember 2013.175

Hasyim, Dardiri. (2017). Identifikasi Pemenuhan Hak Bagi Difabel (Penyandang Cacat) dalam KUHP Perdata. Jurnal Serambi Hukum, Vol.10 No.02 Agustus 2016-Januari 2017, 13-31.

Hutagalung, Novriana Gloria. (2018). Posisi Penting Orang Difabel dalam Masyarakat. Jurnal Ledalero. Vol.17, No2 Desember 2018. 160-176.

Sodikin. (2013). Hukum dan Hak Kebebasan Beragama. Jurnal Cita Hukum. Vol. I No. 2 Desember. 181

Yong, Amos. (2010). Disability and the Gift of the Spirit. Journal of Pentacostal Theology, 19, 76-93. Retrived from https://brill.com/abstract/journals/pent/19/1/a rticle-p76_9.xml

Paul Hidayat (1989). Hakikat dan Fungsi Gereja. Jurnal Pelita Zaman. Volume 4 No.1.

Tarsidi, Dedi. Penyandang Ketunaan: Istilah Pengganti "Penyandang Cacat". Retrieved from Ihttps://pertuni.or.id/penyandang- ketunaan-istilah-pengganti-penyandang$\underline{\text { cacat/ }}$

Suhendar. 2018. Berita Nusantara. Retruived from https://kbr.id/nusantara/12-

2018/ada_ribuan_rumah_ibadah_di_kota_ba ndung baru_dua yang_ramah_disabilitas/9 8537.html

Roy Soselisa. (2018). Retrived from https://www.kompasiana.com/roy.soselisa/55 2ae85ff17e616c4fd624a9/yesus-itu-kaum$\underline{\text { disabilitas }}$

http://www.gkikayuputih.or.id/kesetaraanpenyandang-disabilitas/

Berita Pembangunan Finalisasi RPP Penyandang Disabilitas Indonesia, Kementerian PPN/Bappenas Libatkan Penyandang Disabilitas, November $22^{\text {nd }}$, 201813.37 
